\title{
Amend or repeal? How New Zealand tackled unpopular healthcare legislation
}

\author{
New Zealand has shown that unsuccessful, competition based health legislation can be repealed
}

\author{
Ian Powell executive director, Association of Salaried Medical Specialists, Wellington, New Zealand, \\ Martin McKee professor of European public health, London School of Hygiene \& Tropical Medicine, \\ UK
}

It is now hard to find anyone in England who believes that the 2012 Health and Social Care Act was a good idea, with one senior Conservative politician branding it the greatest mistake of this parliament. ${ }^{1}$ There is, however, less agreement about what to do about it. The BMA has voted overwhelmingly for its repeal, doctors have formed a pressure group with the same aim, ${ }^{2}$ and Labour and Green MPs have introduced an NHS Reinstatement Act to repeal it.

Yet others are more cautious, arguing that, although changes are needed, they should build on rather than tear up the existing legislation. ${ }^{4}$ They contend, firstly, that no one wants another major reorganisation and, secondly, that it is simply impossible to return to what went before.

\section{Failure of the market model}

The first argument has already been disproved, and major legislative change now seems inevitable. The complexities and contradictions of the competition elements of the Health and Social Care Act are seen as unworkable by many, and the roles of regulators such as Monitor and the Care Quality Commission are increasingly unclear. From the outset, general practitioners, seen as leading the new clinical commissioning groups, failed to engage with them. ${ }^{5}$ The large corporations, envisaged as new providers of NHS services, are withdrawing as they realise they cannot make profits without incurring reputational damage. ${ }^{6}$

New approaches are already emerging, such as the integrated system recently announced for Manchester, which bears little resemblance to the fragmented, market oriented vision of the 2012 act.?

But what about the second argument? Can the act be repealed? The experience of New Zealand shows what's possible. In 1993 the National (conservative) government had implemented an "internal market" that went far beyond what was then being espoused by the Thatcher government in Britain. It was based on the belief that market forces, with competition from commercial providers, would enhance effectiveness and efficiency. ${ }^{8}$ Many of the features would be familiar to contemporary observers of the NHS. In theory there was to be no preference between public and private providers (echoing the "any willing provider" provision of the English act). In practice, however, there was a predisposition towards the private sector; previously public services were contracted out; and public hospitals were run by state owned companies governed by the Commerce and Companies Acts, with many of the features of England's foundation trusts.

As the 1990s progressed it became clear that the new model was failing. It led to contradictory and perverse incentives, neglect of workforce development and planning (the legacies of which still plague the system), fiscal irresponsibility, and excessive transaction costs. Nor did it reduce government spending. In 1992 publicly funded health expenditure as a proportion of total health spending was $79 \%$, but by 2000 it was still at $78 \% .{ }^{9}$ In the 1992-93 financial year health expenditure was \$NZ4.88bn, but by $1999-2000$ it had risen by a third to $\$ N Z 6.5 b n$. In the same period, real terms government health spending per capita rose by $23 \%$ from \$NZ1373 to \$NZ1690..$^{10}$

The election of a new Labour led coalition government in late 1999 marked a major break with the prevailing market forces ideology. ${ }^{11}$ The existing legislation was repealed and replaced by the New Zealand Public Health and Disability Act 2000, which took effect in 2001. The decision to repeal and replace rather than amend it was an explicit decision to signify its fundamentally different policy objectives.

The state owned companies were replaced by district health boards responsible for the provision of a comprehensive range of health services for a defined population, with objectives such as improving, promoting, and protecting the health of all people and communities, integration of health services (especially primary and secondary), and reduction of health disparities. The boards were not subject to the Commerce and Companies Acts, and their scope was extended from tertiary and secondary services to include primary and community services. 


\section{Cross party support for more integrated care}

The clear success of the Public Health and Disability Act generated broad political support. When the National Party returned to power in 2008 , leading a coalition government, it strengthened the act, attracting support across the parties. By 2011 an independent analysis concluded that the act had succeeded in integrating planning and funding functions and "assisted in focusing attention on the roles that an enhanced primary care service might play in better supporting integrated care." ${ }^{\prime 2}$ Although that study cautioned that insufficient progress had been made in service delivery, in 2013 the UK health think tank the King's Fund reported how Canterbury District Health Board, in the South Island, had shown that, with clinical leadership, "it is possible to provide better care for patients, reduce demand on the hospital, and flatten or reduce elements of the demand curve across health and social care by improved integration," concluding that what was happening was "transformational." 13

New Zealand has shown that health legislation that focuses on competition and market forces is unsuccessful and unpopular and that "careful crafting of governance, contracting, funding and information sharing" can achieve important benefits by avoiding competition and fragmentation. ${ }^{14}$ However, even more importantly it has shown how it is possible to repeal in its entirety a flawed piece of market based legislation, rather than simply amend it, replacing it with something that can actually deliver integrated care.

\section{Resilience to crises}

Crucially, this new model has proven highly resilient, both to a change of government and, in what was its greatest test, the February 2010 earthquake that hit Christchurch. There is widespread agreement in New Zealand that the Canterbury model of integrated care was critical to mounting a successful response in the face of widespread devastation but that the system in place in the 1990s would have struggled to mount such a response. In England the risk register leaked in 2012 explicitly warned that the Health and Social Care Act could make it more difficult for the NHS to respond to emergencies, ${ }^{15}$ a concern accentuated by experience of the challenge of ascertaining who is responsible for anything. ${ }^{16}$

In 1938 New Zealand's prime minister, Michael Savage, created a national health system, coining the term "from cradle to grave," showing the British government what was possible. Maybe New Zealand is once again offering lessons for England.

Competing interests: None declared.

Provenance and peer review: Commissioned; not externally peer reviewed.

Helm T. Health reform is our biggest mistake in this parliament, says Tory ex-minister Guardian 31 Jan 2015. www.theguardian.com/politics/2015/jan/31/health-reform-toriesbiggest-mistake-parliament-nhs-stephen-dorrell-mp.

2 Limb M. Doctors form new pressure group to prevent "marketisation" of NHS. BMJ 2015;350:h1206.

3 Limb M. Labour promises to abolish competition in NHS and promote "true integration." BMJ 2015;350:h1507.

4 Riley-Smith B. NHS chief executive calls on next government not to implement top-down reorganisation of service. Daily Telegraph Oct 2014. www.telegraph.co.uk/news/health/ news/11181731/NHS-chief-executive-Simon-Stevens-calls-on-next-government-not-toimplement-top-down-reorganisation-of-service.html.

5 White C. GPs are rejecting commissioning roles because of lack of interest. BMJ 2012;344:e4369.

6 lacobucci G. Serco plans to pull out of clinical service provision in the UK. BMJ 2014;349:g5248.

7 lacobucci G. Manchester authority is set to take control of £6bn worth of health and social care spending. BMJ 2015;350:h1110.

8 Powell I. Intellectual origins and principles of the internal market in New Zealand. $N Z$ Med J 2000;113:101-4.

9 Organisation for Economic Co-operation and Development. Health data. OECD, 2015. http://data.oecd.org/health.htm.

10 New Zealand Ministry of Health. Health expenditure trends in New Zealand 2000-2010. Ministry of Health, 2012. www.health.govt.nz/publication/health-expenditure-trends-newzealand-2000-2010.

11 Devlin N, Maynard A, Mays N. New Zealand's new health sector reforms: back to the future? BMJ 2001;322:1171-4

12 Cumming J. Integrated care in New Zealand. Int J Integrated Care 2011;11:e138.

13 Timmins N, Ham C. The quest for integrated health and social care: a case study in Canterbury, New Zealand. King's Fund, 2013. www.kingsfund.org.uk/publications/questintegrated-health-and-social-care.

14 Mays N, Smith J. What can England's NHS learn from Canterbury New Zealand? BMJ 2013;347:f6513.

15 Watt N, Ramesh R. Health reforms could damage NHS, warns draft risk register. Guardian Mar 2012. www.theguardian.com/politics/2012/mar/27/health-reforms-damage-nhs-riskregister.

16 Thomas K. What the healthcare sector wants from the next government. Guardian Mar 2015. www.theguardian.com/healthcare-network/2015/mar/10/healthcare-sector-wantsnext-government.

Cite this as: BMJ 2015;350:h1502

(C) BMJ Publishing Group Ltd 2015 